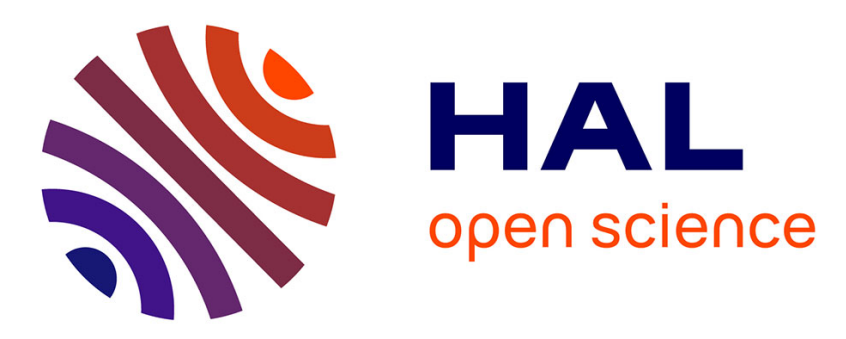

\title{
Market Structure and Innovation Policies in France
}

Matthieu Lardeau

\section{To cite this version:}

Matthieu Lardeau. Market Structure and Innovation Policies in France. Hans van Kranenburg. Innovation Policies in the European News Media Industry: A Comparative Study, pp.193 - 83, 2017, 9786. 10.1007/978-3-319-45204-3_6. hal-01508746

\section{HAL Id: hal-01508746 \\ https://hal.uca.fr/hal-01508746}

Submitted on 18 Apr 2017

HAL is a multi-disciplinary open access archive for the deposit and dissemination of scientific research documents, whether they are published or not. The documents may come from teaching and research institutions in France or abroad, or from public or private research centers.
L'archive ouverte pluridisciplinaire HAL, est destinée au dépôt et à la diffusion de documents scientifiques de niveau recherche, publiés ou non, émanant des établissements d'enseignement et de recherche français ou étrangers, des laboratoires publics ou privés. 


\title{
Market Structure and Innovation Policies in France
}

\author{
Matthieu Lardeau
}

\section{$1 \quad$ Market Structure and Media Ownership}

The news media industry in France has a long tradition. Le Mercure François is known as the first news review. It started to appear in 1611. In 1631, Théophraste Renaudot launched the first periodical paper, La Gazette. The first daily newspaper appeared in 1777: Le Journal de Paris. In 1830s, France became known as one of the three pioneers of the modern daily press in Europe. At that time, the newspaper industry was very innovative. For instance, the French penny press based on a new business model was introduced by journalist entrepreneurs Emile de Girardin and Armand Dutacq. They founded La Presse and Le Siècle in June and July 1836 respectively. These mass newspapers offered a content mixing news, romanfeuilleton and commercials. Due to the mass production, they could offer a lower subscription price (Eveno, 2003). In 1863, Moïse Millaud launched Le Petit Journal. It used an innovative business model based on the use of modern printing machine (de la Motte and Przyblyski, 1999). In the turmoil after World War II (1944-1947), the evolution of the printed press was influenced by the intervention of the French government. The government decided to set conditions on the structure of the newspaper market with strong constraints.

Although France played an important role in the development of the press and freedom of the press for centuries, it does not have a leading position anymore. France is ranked 38th in the world regarding the press freedom index (Reporters Sans Frontières, 2015). The main reason for this position is that France does not provide effective protection for the confidentiality of journalists' sources.

\footnotetext{
M. Lardeau $(\bowtie)$

Université Blaise-Pascal, Clermont-Ferrand, France

IUT d'Allier Département Techniques de Commercialisation, CRCGM Université de Clermont Auvergne, Avenue Aristide-Briand, 03100 Montlucon, France

e-mail: matthieu.lardeau@essec.edu; Matthieu.Lardeau@univ-bpclermont.fr
} 
The consumption of news media has gradually increased in France in the last two decades (Médiamétrie, 2014). In 2014, $86.6 \%$ of French population watched daily television (compared to $85.7 \%$ in 2004 and $89.3 \%$ in 2009) through all different devices (TV set, computer, tablet, mobile phones). They watched daily television on average $3 \mathrm{~h}$ and $41 \mathrm{~min}$. On average each household was equipped with 6.5 screens (TV set, computer, mobile phone, tablet). $30 \%$ of households (6.4 million) were equipped with TV set, tablet, and laptop. 43.3 million people in France listen daily on average $3 \mathrm{~h}$ to at least a radio channel. Internet has also become popular. Around $80 \%$ of France inhabitants (43.5 million) are Internet-users and 23 million spend on average $1 \mathrm{~h}$ and $16 \mathrm{~min}$ each day on Internet.

Since 2010 the news media landscape has dramatically changed in France. Less and less families own and run the newspapers they launched many decades ago. In 2010, the group Le Monde was acquired by a trio of French billionaires: Xavier Niel who is a technology and media entrepreneur, the founder of Iliad, an (Benyahia-Kouider, 2011) Internet access service provider and telecommunications services; Pierre Bergé, the partner of fashion mogul Yves Saint-Laurent and who is the founder and investor of left-wing magazines (Globe to support François Mitterrand, Courrier International) and gay magazine (Tetu); Matthieu Pigasse, the vice-president of the investment bank Lazard in Europe and owner of the cultural magazine Les Inrockuptibles and the radio broadcaster Nova. The change in the shareholding structure of Le Monde is substantial. Since the creation of the most respected French daily in 1944, it has been run by its journalists, in particular by the Société des Rédacteurs du Monde (SRM) since 1951. In 2010, when the trio of tycoons (Bergé-Niel-Pigasse) made a financial takeover of Le Monde to save it from bankruptcy by acquiring more than $60 \%$ of share capital, the SRM was not part of the directing board anymore. In December 2015 the group Le Monde expressed an interest in buying LCI, the 24-h news TV channel owned by group TF1.

Another entrepreneur Vincent Bolloré became active in the French media market in 2005 by creating the TV channel Direct 8 . He also launched the free daily newspaper group Direct Matin in 2007. In 2015, Bolloré takes a control share of $60 \%$ in Havas, one of the largest global communication consultancy groups. In the last decade the Bolloré group, a paper-energy-plantations-logistics conglomerate, became the first shareholder of the Vivendi group (TV channels Canal+ and itélé). Patrick Drahi, the founder of a Luxemburg-based group Altice operating in telecommunications (SFR-Numericable and Virgin Mobile) has also started to invest in news media markets. In 2014, he acquired the left-wing socialist newspaper Libération, the group and newsmagazine L'Express and the group NextRadioTV. In 2015, Altice Media had a 300 million euros turnover. In October 2015, another wealthy businessman (P. Drahi) became the main shareholder of Liberation and Le Parisien and Aujourd'hui en France were sold for 500 million euros by the Amaury family group to LVMH Médias (B. Arnault) that already owns Les Echos. The newspaper Le Figaro is controlled by the weapons' and aerospace equipment group Dassault since 2004.

Only the communist daily L'Humanité, the new-launched conservative daily L'Opinion and the far-right newspaper Présent do not belong to holdings or 
conglomerates as well as the sports daily L'Equipe that is held by Amaury, a family-owned publishing company. The catholic daily La Croix is the flagship paper of Bayard, a media and publishing group.

In terms of turnover (source: company websites), four big private media companies have been emerged in France. Canal Plus (held by the group Vivendi run by the mogul Vincent Bolloré) that only operates in the television market with four TV channels: Canal+, itélé, D8 and D17 (turnover of 2.7 billion euros in 2015); the German media company Bertelsmann that owns TV channels (M6), radio broadcast (RTL) and magazine press (Prisma) (turnover of 2.4 billion euros in 2015); the third company is Groupe TF1 (owned by Bouygues). It operates TV channels (TF1, LCI) and one free daily (Metro) (turnover of 1.6 billion euros in 2015). The fourth largest company is Lagardère Active that operates in all media markets (TV, radio, press, Internet) (turnover of 958 million euros in 2015). Table 1 shows the ownership of the most important media groups in the news media markets in France.

\section{$1.1 \quad$ Newspapers}

In the first semester of 2015, 3403 press outlets edited by French editors have been issued in France (loss of $4.5 \%$ compared to 2014) split into 76 newspapers titles and 3358 magazines titles. The overall turnover of French print press is declining year after year: a loss of $6.46 \%$ between 2012 and 2013 and $4.24 \%$ between 2013 and 2014 (Ministère de la Culture et de la Communication, 2016). The newspaper market lost more than 2 billion euros of advertising revenues between 2006 and 2014. The turnover for 2014 was 7.81 billion euros (a loss of $4.2 \%$ compared to 2013). Actually, the total turnover declines year after year since 2007. The turnover is composed of two-third from mainly subscription and one third from advertising revenues.

Hence, the French daily newspaper market is characterized by the following trends: a constant decline of advertising revenues (that mainly migrate to Internet sites) and readership. As a consequence, the copy selling price of newspapers increased and their (Albert and Sonnac, 2015) newsrooms had to downsize (through numerous lay-offs and predominance given to work with freelance journalists). Table 2 shows the decline of overall circulation of newspapers since 1946 with some exceptions for a few dailies.

The regional newspaper market also shows an increase in concentration. Historically, almost all 22 French metropolitan regions have been dominated by one regional independent newspaper (with one edition dedicated to each county). In the last two decades, this market is driven by a huge ownership reconfiguration through mergers and acquisitions in favor of most profitable regional press groups. As of today, the company EBRA (owned by the bank Crédit Mutuel) covers the north-east of France, La Dépêche and Sud Ouest share the South West market, Ouest-France rules the West region, and group La Voix (owned by the Belgian media holding Rossel) dominates the North and Centre-France controls the center of France.

In the newspaper market the latest innovation was the launch of free dailies (after their inception in Sweden and Norway in 1997): in 2002, 20 Minutes and 
Table 1 An overview of the largest media groups in France in 2015

\begin{tabular}{|c|c|c|c|c|c|}
\hline $\begin{array}{l}\text { Group } \\
\text { (ownership) }\end{array}$ & $\begin{array}{l}\text { Turnover } \\
\text { in euros }\end{array}$ & TV & Radio & Print press & Internet $^{\mathrm{b}}$ \\
\hline French State & $\begin{array}{l}3.9 \\
\text { billion } \\
(2014)\end{array}$ & $\begin{array}{l}\text { France TV } \\
\text { group: } \\
6 \text { channels } \\
\text { + LCP, Public } \\
\text { Sénat, France } \\
24, \text { TV5 } \\
\text { Monde, } \\
\text { ARTE }(50 \%)\end{array}$ & $\begin{array}{l}\text { Radio } \\
\text { France } \\
\text { group: } 7 \\
\text { + RFI, } \\
\text { Monte } \\
\text { Carlo } \\
\text { Doualiya }\end{array}$ & I & Ina.fr \\
\hline $\begin{array}{l}\text { Canal+ } \\
\text { (Vivendi/V. } \\
\text { Bolloré) }\end{array}$ & $\begin{array}{l}2.7 \\
\text { billion }\end{array}$ & $\begin{array}{l}\text { Canal+, Itélé, } \\
\text { D8, D17 }\end{array}$ & l & $\begin{array}{l}\text { Direct Matin } \\
\text { Direct Sport }\end{array}$ & \\
\hline $\begin{array}{l}\text { RTL } \\
\text { (Bertelsmann) }\end{array}$ & $\begin{array}{l}2.4 \\
\text { billion }\end{array}$ & $\begin{array}{l}8 \text { incl. M6, } \\
\text { W9, 6ter, } \\
\text { Paris } \\
\text { Première }\end{array}$ & $\begin{array}{l}\text { 3: RTL, } \\
\text { RTL2, } \\
\text { Fun }\end{array}$ & $\begin{array}{l}\text { Prisma Media } \\
\text { group } \\
\text { (19 magazines } \\
\text { incl. Geo, } \\
\text { Capital, Voici, } \\
\text { VSD) }\end{array}$ & \\
\hline $\begin{array}{l}\text { TF1 } \\
\text { (Bouygues) }\end{array}$ & $\begin{array}{l}1.6 \\
\text { billion }\end{array}$ & $\begin{array}{l}9 \text { incl. TF1, } \\
\text { LCI, TMC, } \\
\text { NT1, HD1, } \\
\text { Histoire }\end{array}$ & l & I & $\begin{array}{l}\text { metronews. } \\
\text { fr }\end{array}$ \\
\hline $\begin{array}{l}\text { Lagardère } \\
\text { Active } \\
\text { (Lagardère) }\end{array}$ & $\begin{array}{l}958 \\
\text { million }\end{array}$ & $\begin{array}{l}11 \text { incl. } \\
2 \text { children TV } \\
\text { (Gulli, TiJi), } \\
6 \text { music TV }\end{array}$ & $\begin{array}{l}\text { 3: Europe } \\
\text { 1, Virgin, } \\
\text { RFM }\end{array}$ & $\begin{array}{l}1 \text { newspaper: } \\
\text { Journal du } \\
\text { Dimanche }+13 \\
\text { magazines } \\
\text { incl. Elle, Paris } \\
\text { Match }\end{array}$ & $\begin{array}{l}15 \text { sites incl. } \\
\text { Newsweb } \\
\text { Doctissimo } \\
\text { Psychologies }\end{array}$ \\
\hline $\begin{array}{l}\text { LVMH Media } \\
\text { (LVMH/B. } \\
\text { Arnault) }\end{array}$ & $\begin{array}{l}500 \\
\text { million }\end{array}$ & / & $\begin{array}{l}\text { Radio } \\
\text { Classique }\end{array}$ & $\begin{array}{l}\text { Les Echos, Le } \\
\text { Parisien, } \\
\text { Aujourd'hui en } \\
\text { France, } \\
\text { Investir }\end{array}$ & \\
\hline $\begin{array}{l}\text { Le Figaro } \\
\text { (Dassault } \\
\text { Media) } \\
\end{array}$ & $\begin{array}{l}500 \\
\text { million }\end{array}$ & I & / & Le Figaro & $\begin{array}{l}\text { CCM } \\
\text { Benchmark }\end{array}$ \\
\hline $\begin{array}{l}\text { Amaury } \\
\text { (Amaury } \\
\text { family) }\end{array}$ & $\begin{array}{l}440 \\
\text { million }\end{array}$ & $\begin{array}{l}\text { 1: L'Equipe } \\
21\end{array}$ & I & $\begin{array}{l}1 \text { daily: } \\
\text { L'Equipe + } 5 \\
\text { sports } \\
\text { magazines }\end{array}$ & \\
\hline $\begin{array}{l}\text { La Vie-Le } \\
\text { Monde } \\
\text { (P. Bergé, } \\
\text { X. Niel, } \\
\text { M. Pigasse) }\end{array}$ & $\begin{array}{l}400 \\
\text { million }\end{array}$ & I & I & $\begin{array}{l}\text { Le Monde, } \\
\text { Télérama, } \\
\text { L'Obs, } \\
\text { Courrier } \\
\text { international, } \\
\text { Le Monde } \\
\text { diplomatique, } \\
\text { la Vie }\end{array}$ & Rue89 \\
\hline
\end{tabular}


Table 1 (continued)

\begin{tabular}{|c|c|c|c|c|c|}
\hline $\begin{array}{l}\text { Group } \\
\text { (ownership) }\end{array}$ & $\begin{array}{l}\text { Turnover } \\
\text { in euros }\end{array}$ & TV & Radio & Print press & Internet $^{\mathrm{b}}$ \\
\hline $\begin{array}{l}\text { Bayard } \\
\text { (Augustinians } \\
\text { of the } \\
\text { Assumption) }\end{array}$ & $\begin{array}{l}353 \\
\text { million }\end{array}$ & I & / & $\begin{array}{l}1 \text { daily: } \mathrm{La} \\
\text { Croix } \\
+ \text { numerous } \\
\text { magazines }\end{array}$ & \\
\hline $\begin{array}{l}\text { Altice Média } \\
\text { Group } \\
\text { (P. Drahi) }\end{array}$ & $\begin{array}{l}300 \\
\text { million }\end{array}$ & 8 & I & $\begin{array}{l}1 \text { daily: } \\
\text { Libération } \\
(50 \%)+20 \\
\text { magazines } \\
\text { incl. L'Express }\end{array}$ & \\
\hline $\begin{array}{l}\text { NextRadio TV } \\
\text { (A. Weill) }\end{array}$ & $\begin{array}{l}195 \\
\text { million }\end{array}$ & $\begin{array}{l}\text { 5: BFM TV, } \\
\text { BFM } \\
\text { Business, } \\
\text { RMC } \\
\text { découvertes, } \\
\text { RMC TV, } \\
\text { Numéro } 23\end{array}$ & $\begin{array}{l}\text { 2: RMC } \\
(99.9 \%), \\
\text { BFM } \\
\text { business } \\
\text { radio }\end{array}$ & I & $\begin{array}{l}8 \text { sites incl. } \\
\text { 01net }\end{array}$ \\
\hline $\begin{array}{l}\text { Mondadori } \\
\text { France } \\
\text { (S. Berlusconi) }\end{array}$ & $\begin{array}{l}167 \\
\text { million }\end{array}$ & I & I & 31 magazines & \\
\hline $\begin{array}{l}\text { Artémis } \\
\text { (F. Pinault) }\end{array}$ & $\begin{array}{l}85 \\
\text { million }\end{array}$ & I & / & $\begin{array}{l}\text { Le Point, } \\
\text { L'Agefi hebdo, } \\
\text { l'Agefi actifs }\end{array}$ & \\
\hline
\end{tabular}

ahttp://www.la-croix.com/Actualite/Economie-Entreprises/Economie/La-transformationnumerique-accroit-la-concentration-des-medias-2015-12-06-1389316

${ }^{\mathrm{b}}$ Not including the websites of TV, radio, and press outlets

Metro (closed down in 2015) and in 2006 Direct Matin and Direct Soir (closed down in 2010). However in 1994, the inception of the daily InfoMatin appeared as a business and editorial innovation: the content offered a mix of hard and soft news through shorter articles than the other dailies and with a selling price half of the competitors. In 1996, it had to close down due to the inability to reach break-even, however InfoMatin can be seen as a forerunner of 20 Minutes and Metro. Although numerous dailies (national and regional) closed down during the latest decades due to precisely a lack of innovation of their business model and/or editorial content, new national dailies were established in this period. These newspapers are Libération (1973), Le Quotidien de Paris (1974-1996), Le Matin de Paris (1977-1987), J'informe (09-12.1977), Présent in 1982, Aujourd'hui en France in 1996, and L'Opinion in 2013. Table 3 presents an overview of the national daily newspapers in France in 2015.

An interesting and recent innovation in the French print press pertains to the new segment of "mooks" (a word mixing magazine and book). Mooks are periodical review (mostly quarterly) that mix features of magazines and books. The first mook, the quarterly XXI, was created in France in 2008. It offers innovation in delivering a new kind of journalism through very long form papers, new kind of journalism 


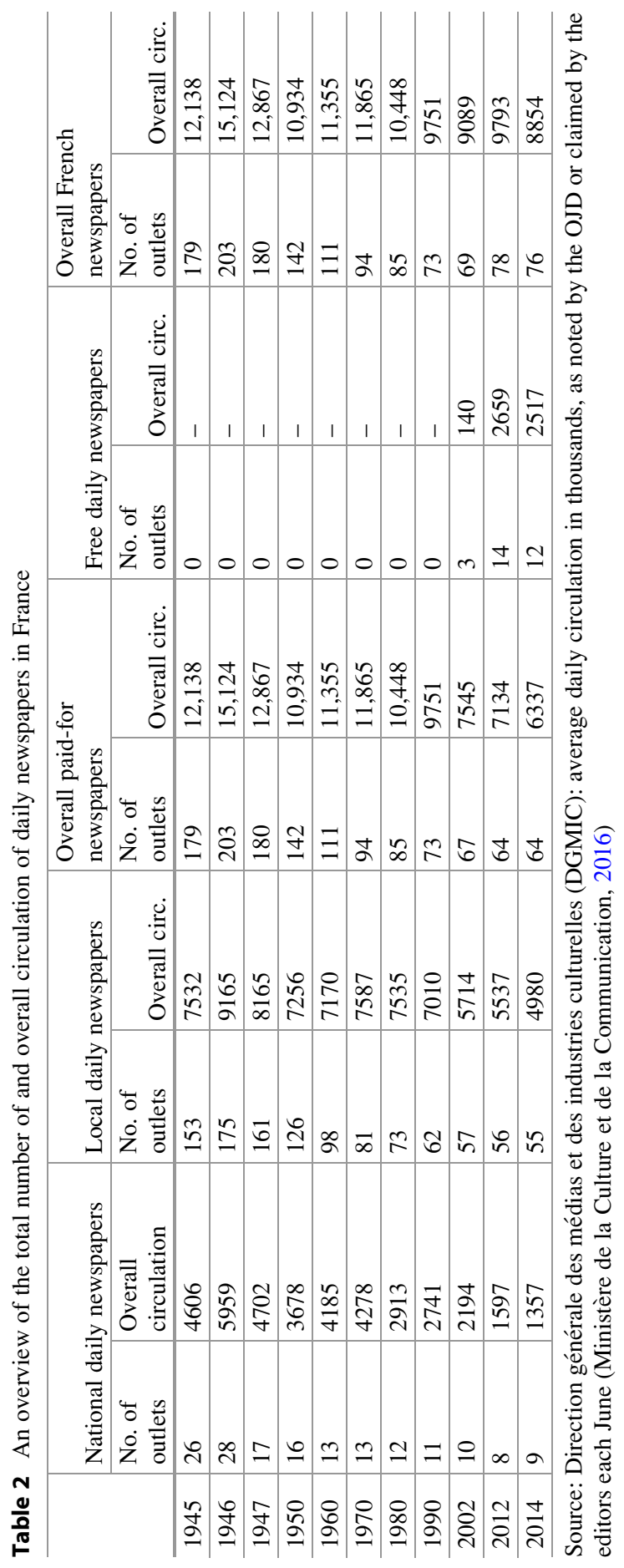


Table 3 An overview of the national daily newspapers in France ${ }^{a}$

\begin{tabular}{l|l|l|l|l|l}
\hline Newspaper (year of launch) & 1981 & 2000 & 2007 & 2012 & 2014 \\
\hline Le Figaro (1854) & 336 & 368 & 327 & 323 & 311 \\
\hline La Croix (1883) & 118 & 90 & 97 & 94 & 104 \\
\hline L'humanité (1904) & 141 & 55 & 51 & 44 & 40 \\
\hline Les Echos (1908) & 67 & 154 & 119 & 122 & 128 \\
\hline Le Monde (1944) & 439 & 402 & 317 & 288 & 297 \\
\hline Le Parisien (1944) & 343 & 492 & 336 & 274 & 237 \\
\hline L'équipe (1946) & 223 & 401 & 323 & 275 & 255 \\
\hline Libération (1973) & 70 (est.) & 171 & 132 & 119 & 97 \\
\hline Présent (1982) & $/$ & n.a. & 8 (est.) & n.a. & n.a. \\
\hline Aujourd'hui en France (1996) & $/$ & 131 & 187 & 179 & 152 \\
\hline 20 minutes (2002) & $/$ & $/$ & 718 & 957 & 968 \\
\hline Direct Matin (2006) & $/$ & $/$ & & 910 & 904 \\
\hline L'opinion (2013) & $/$ & $/$ & $/$ & $/$ & 35 \\
\hline Sonce: Dis & & & & &
\end{tabular}

Source: Direction générale des médias et des industries culturelles (DGMIC): average daily circulation in thousands, as noted by the OJD or claimed by the editors each June (Ministère de la Culture et de la Communication, 2016)

aThis table made by the DGMIC doesn't integrate the national daily far-right newspaper, Présent, launched in 1982, that only publish five issues a week

mixing literary and investigative, journalism through comics, etc. The creators of XXI acted as entrepreneurs or intrapreneurs. The primary idea came from the market and behavior of readers and expectations. With the development of this mook, the creators referred to the essence of journalism in order to base their project on the substance of journalism, and finally they defined a compliant business model (Lardeau, 2013).

Not surprisingly the online news press market is flourishing for about one decade. Many news websites have been launched although they do not rely on innovation spirit and initiative. A major exception was the launch of mediapart.fr in 2008. Created by veteran journalists who leaved the old daily press and created a distinctive editorial and online business model. The content covers only hard news mainly through investigative journalism and access of content offered by journalists are subject to subscription and content offered by citizens is for free. In return mediapart.fr is refusing any kind of commercials or advertising revenues. The organization was profitable in less than 4 years. Mediapart.fr is one of the few subscription news websites that survives in a market highly dominated by news providers relying on a basic business model with editorial content for free and revenues coming from advertising content and commercials. 


\subsection{Television}

The first TV station in France was launched in 1931. During the following decades the television market gradually grew through the increasing number of TV set in households and the number of TV channels. In 1949, only 297 households had a TV set and only one TV channel was allowed to operate on the television market. This TV channel was owned by the French government. In 1965, $40 \%$ of French people had a TV set to watch two State-owned channels. The first major turn took place in 1975 when the President of the French Republic, V. Giscard d'Estaing, broke the State monopoly and allowed the creation of a third channel. A second major turn appeared in the 1980 s when private channels were allowed to enter the market (Canal+ (the first pay-per-view TV station launched in 1984), M6, La Cinq) and a public one, ARTE (1992) in association with the German State. The aim of ARTE was to promote a common culture.

In the last two decades, the television landscape in France changed significantly (Gabszewicz and Sonnac, 2010) and became less concentrated. Until the beginning of 2000, the French households had only access for-free to less than 10 national TV channels. The Digital terrestrial television (Télévision Numérique Terrestre, TNT) has been launched in March 2005: this system then offers 14 TV channels including 5 new ones. In 2015, France's TNT offers 25 free national channels and 9 pay channels, plus up to 4 local free channels.

The different channels cover three traditional categories of business models: public (financed by public taxes: all the channels of France TV group), private for free (predominantly financed by the advertising and commercials) and private pay-TV (Canal+ that offers free programs although many of them require a subscription, and all the TV channels included the subscription television packages via satellite).

The French TV market is dominated by four major media companies. The Stateowned group, France Television (turnover: 2.96 billion euros in 2013) operates five channels in 2015 that all are available for free and financed by public taxes. The other three companies are private. TF1, the largest European private TV channel, is the main TV channel of group Bouygues, an international large industrial holding primarily operating in construction, real estate development, and it has also business in telecoms and media (turnover of TF1 group: 2.470 billion euros in 2013). RTL group is a leading European entertainment company that runs M6 Group (turnover: 1.38 billion euros in 2013) in France whose TV flagship is M6. Canal+ group (turnover: 1.88 billion euros in 2013) includes four TV channels (Canal+, D8, D17, itélé) and its holding company, Vivendi, has been led since June 2014 by Vincent Bolloré, a French major moguls. The Table 4 presents an overview of the market shares and audience of the main broadcasters in France. 
Table 4 An overview of the market share of national TV channels in France in 2015

\begin{tabular}{|c|c|c|c|}
\hline Group & TV channel & Market share (\%) & Audience \\
\hline \multicolumn{4}{|l|}{ General news } \\
\hline TF1/Bouygues (p) & TF1 & 21.4 & 53,994 \\
\hline France TV $(\mathrm{P})$ & France 2 & 14.4 & 51,108 \\
\hline M6/RTL (p) & M6 & 10.1 & 50,858 \\
\hline France TV $(\mathrm{P})$ & France 3 & 9.1 & 50,549 \\
\hline Vivendi/Bolloré (p) & D8 & 3.4 & 42,520 \\
\hline France TV $(\mathrm{P})$ & France 5 & 3.3 & 42,723 \\
\hline Vivendi/Bolloré (p) & Canal+ & 2.5 & 33,006 \\
\hline France \& Germany States $(\mathrm{P})$ & ARTE & 2.2 & 39,529 \\
\hline France TV $(\mathrm{P})$ & France 4 & 1.8 & 38,331 \\
\hline \multicolumn{4}{|l|}{ Breaking news channels } \\
\hline News Participation (p) & BFM TV & 2.0 & 32,784 \\
\hline Vivendi/Bolloré (p) & i>télé & 0.9 & 27,762 \\
\hline \multicolumn{4}{|l|}{ Sports channel } \\
\hline Amaury/LVMH (p) & L'Equipe 21 & 0.6 & 21,087 \\
\hline
\end{tabular}

Source: Enquête Médiamat mensuel, septembre 2015, (Médiamétrie, 2015a)

$P$ public, State-owned; $p$ private, commercial

\subsection{Radio Broadcasting}

The French radio broadcasting landscape can be categorized based on the nature of ownership (State-owned, commercial and community) and the scope of audience (national vs. regional/local). Between April and June 2015, 81.1\% of teenagers and adults in France listened to at least one radio station each week-day. On average $67.2 \%$ of the audience listens to commercial stations, $24.3 \%$ listens to state-owned stations, $2.3 \%$ listens community stations and $4.6 \%$ listens to others (Médiamétrie, $2015 \mathrm{~b}$ ). Regarding the nature of programs, $40.6 \%$ of the audience listens to music radios, $37.6 \%$ to general programs (news and entertainment), $20.2 \%$ to local programs and $12.4 \%$ to thematic programs (cultural programs, breaking news, classical music). French teenagers and adults use to listen to the radio on average $3 \mathrm{~h}$ a week-day and most of them listen to more than one radio station during a day.

At national level two NRJ and RTL compete with each other. Launched in 1981, NRJ (NRJ group) is the leading music radio station for young people (teenagers and young adults) and the most popular radio station $(9.2 \%$ of "audience cumulée $(\mathrm{AC})^{1}$ "). RTL, a French commercial radio network owned by the Luxembourgish RTL group, is the leading national commercial and news station that offers news,

\footnotetext{
${ }^{1}$ One of the three main indicators of radio (and TV) audience in France measured by Médiamétrie is the "audience cumulée" that measures the percentage of over 13 years-old people living in France who listen the radio channel at least once the previous day. The second indicator is the average listening time of a radio (or TV) channel a day by a listener ("durée d'écoute par auditeur"). The third indicator is the regular market share ("part d'audience").
} 
talk and entertainment programs. RTL is the second most listened radio station in France ( $8.7 \%$ of "AC").

State-owned radio stations belong to the group Radio France. Its nationwide stations cover general news (France Inter), 24-h breaking news (France Info), culture (France Culture), classical music (France Musique), jazz music (FIP), pop music and youth (le Mouv'). In addition, Paris-based RFI covers international news through its worldwide correspondents in 13 different languages.

At local level the main radio stations are the local France Bleu stations and a wide range of community and commercial radio stations that mainly broadcast music programs (FM stations). The France Bleu network runs local stations covering local news.

The radio broadcasting market has a dual market structure. It is limited concentrated at the local level but quite concentrated at the national level, except from the public sector that is only covered by Radio France, the State-owned radio stations group (turnover: 645.5 million euros in 2014). However most of commercial radio channels belong to media or non-media groups that also own other media outlets (TV, newspapers, magazines and online media): For instance, RTL group runs RTL, and two music commercial channels: RTL2 and Fun Radio. Lagardère Active operates three radio channels: Europe1 and two music commercial radios: RFM and Virgin Radio. NextRadioTV owns RMC and BFM radio. This group founded and directed by Alain Weill has been included in the News Participation holding - co chaired by A. Weill and P. Drahi-in July 2015. Table 5 presents an overview of the main radio stations and the audience share, average listening time a day and market share.

\section{Regulations}

In the last decades, France had different rules and laws designed to constrain and limit cross-ownership in the news media markets. The claim of the legislation was to protect news media pluralism of political ideas, outlets and firms, and limit the power of big media companies in the news media markets. The interventionist legislation is rooted in the substantive role historically played by the French State in the different news media markets. In 1944-1945 the French State ensured pluralism of opinions and free competition in the national and political newspaper market, but at the same time public authorities did not break down the nascent monopolies in each region that contradict pluralism of opinions and free competition in the daily newspaper market.

The State and its numerous controlled or dependent agencies were supposed to guarantee the independence of media and pluralism. The structure of the news media markets have been influenced by the French State and its organizations (Charon, 1991; de Tarlé, 1980; Freiberg, 1981). For instance, the Direction Générale des Médias et des Industries Culturelles (DGMIC), an agency of the Ministry of Culture and Communication, is partly dedicated to monitor the 
Table 5 An overview of the leading radio stations in France in 2015

\begin{tabular}{|c|c|c|c|c|}
\hline Group & Radio station & $\begin{array}{l}\mathrm{AC} \text { in } \\
\text { percent }\end{array}$ & $\begin{array}{l}\text { DEA } \\
(\mathrm{h} / \mathrm{min})\end{array}$ & $\begin{array}{l}\text { Market share in } \\
\text { percent }\end{array}$ \\
\hline \multicolumn{2}{|l|}{ General programs } & 30.7 & 2 h 20 & 40.4 \\
\hline RTL (p) & RTL & 8.9 & 2 h 18 & 11.4 \\
\hline Radio France $(\mathrm{P})$ & France Inter & 7.8 & 2 h 07 & 9.3 \\
\hline Lagardère (p) & Europe 1 & 7.6 & $1 \mathrm{~h} 52$ & 7.9 \\
\hline Radio France $(\mathrm{P})$ & France Bleu & 6.0 & 2 h 13 & 7.5 \\
\hline NextRadioTV (p) & RMC & 4.6 & $1 \mathrm{~h} 38$ & 4.2 \\
\hline \multicolumn{2}{|l|}{ Music programs } & 31.8 & $1 \mathrm{~h} 46$ & 31.6 \\
\hline NRJ Group (p) & NRJ & 9.2 & $1 \mathrm{~h} 23$ & 7.2 \\
\hline Nakama (p) & Sky Rock & 5.3 & $1 \mathrm{~h} 22$ & 4.1 \\
\hline \multicolumn{2}{|l|}{ Topical programs } & 10.1 & 1 h 37 & 9.1 \\
\hline Radio France (P) & France Info & 5.7 & 0 h 57 & 3.1 \\
\hline $\begin{array}{l}\text { Les Echos-LVMH } \\
\text { (p) }\end{array}$ & $\begin{array}{l}\text { Radio } \\
\text { Classique }\end{array}$ & 2.0 & $2 \mathrm{~h} 06$ & 2.4 \\
\hline Radio France $(\mathrm{P})$ & France Culture & 1.8 & 1 h 59 & 2.1 \\
\hline Radio France $(\mathrm{P})$ & $\begin{array}{l}\text { France } \\
\text { Musique }\end{array}$ & 1.2 & $1 \mathrm{~h} 39$ & 1.1 \\
\hline \multicolumn{2}{|c|}{$\begin{array}{l}\text { Local and community programs } \\
\text { (691 radio stations) }\end{array}$} & 15.6 & $1 \mathrm{~h} 46$ & 15.6 \\
\hline
\end{tabular}

Source: Enquête Médiamétrie 126.000 radio, avril-juin 2015, (Médiamétrie, 2015b)

$P$ public, State-owned; $p$ private, commercial

allowance of numerous and substantial public subsidies to newspapers and magazines (Lardeau and Le Floch, 2014). Companies can enter with no restrictions the newspaper market although economic barriers are high in this market. However the law of 23 October 1984 (modified by the law of 28 November 1986) puts two main limits on free entry: one press group (1) cannot control more than $30 \%$ of the total circulation of newspapers and (2) cannot be the major shareholder of media firms in more than two of the following media markets (newspaper, radio broadcasting, terrestrial TV, cable TV). Actually this law has never limited nor blocked the process of concentration in the regional newspapers market or media crossownership across the different news media markets.

However, the television and radio broadcasting markets are more regulated. Broadcasting companies or stations need a license to operate in these markets. The Conseil Supérieur de l'Audiovisuel (CSA) decides whether a company or station can receive a license. One of the main activities of CSA is to allocate frequencies to TV and radio operators and to limit the number of frequencies. A broadcast company or station should fulfill three conditions before a license will be provided by the CSA. The first condition to launch a radio station (nationwide or FM) is that a frequency has to be vacant and on the market. The second condition is that the project has to be compliant with specific requirements defined by the CSA and finally the station has to win the competition for the license set by the CSA. 
Therefore, the number of television and radio broadcasting stations are limited in France. Furthermore, the CSA can limit the cross-ownership in the both markets.

Although the intentions and actions of the French government and Parliament are to limit concentration in the news media markets, they failed to successfully implement the intentions and actions (Charon, 1991; Eveno, 2003; Lardeau and Le Floch, 2014; Le Floch and Sonnac, 2005). It is even expected that news media concentration is going to advance in the coming years. The first reason is that political parties and representatives prefer to ensure their personal and professional interests, relationships with managers and owners of media and journalists (Kuhn, 1995). Secondly, they claim that some ownership concentration in a news market or media cross-ownership is allowed to increase survival chances of media.

\section{$3 \quad$ Media Innovation Policies}

In the nineteenth century, the French news media sector was one of the most innovative industries in the world. In the last decades, the news media companies are failing to demonstrate a clear vision and capabilities to innovate, although for many years the French State and governments - and their associated bodies-have been implementing innovation policies in the news media markets. Nowadays, the French news media sector is not infused nor formed by innovation spirit or initiative. The French State and public authorities that play a pivotal role in this sector never acted to promote, support or carry on innovation. They did not clearly defined "the rationales and objectives of policy intervention to support innovation, as well as the policy instruments used" (Innovation Policy Platform, 2016); nor did the news media companies and knowledge institutions such as universities and research centers.

De facto media companies and people in France are not focused on innovation in terms of editorial, business or technology issues. As a consequence, innovation journalism and even entrepreneurial journalism are left behind in France (Lardeau, 2009). Innovation Journalism refers to journalism focused on media practices that trigger and generate innovation in journalism practices and references (Nordfors, 2004). Entrepreneurial Journalism refers to journalists or media individuals who create from scratch new jobs or media organizations in journalism, marketing and business, organization design, etc. Both types of innovations require that journalists and media people "think out of the box" and challenge the taken for granted ideas, practices and references in order to make effective change and innovation in journalism and news media sector.

Due to the lack of innovation spirit and initiatives in the news media landscape, former President of the Republic Nicolas Sarkozy pledged to help the sector (600 million euros for 3 years) in initiating the "Etats généraux de la presse" in 2009. This so-called national press conference was assigned two goals. The first goal was to initiate debates among the journalism profession on how to promote and make effective editorial, technological, and business innovations in order to stop the decline of readership of newspapers and keep the press alive, pluralistic, and 
independent. The second goal was to survey the sophisticated system of State financial aid for newspapers and to come with recommendations to make the system more simple and efficient. Furthermore, the national press conference supported newspaper companies to get through the financial crisis and to refine their business model in a more sustainable way (Lardeau and Le Floch, 2014). However, the national press conference did not lead to a reconfiguration of the newspaper business nor to effective proceedings in line with the initial claim. On the contrary, this conference reinforced immobility and could not stop the concentration tendency in the newspaper industry. Another intervention of the French government was the establishment of the "Fonds stratégique pour le développement de la presse" (Strategic Press Development Fund). This fund allocates direct aids and grants to print and online newspapers that are supposed to set innovative projects to modernize and shift print to online. In 2014, this Fund distributed 22.8 million euros to support 117 projects (Ministère de la Culture et de la Communication, 2015). Around $81 \%$ of the support was for the traditional general newspapers. Less than $16 \%$ of the support was allocated to online migration or digitization projects and around $42.5 \%$ was allocated to "management and newsroom issues" (that means it covers running costs and salaries) and $31 \%$ of the financial support was spent on financing printing machines. This Fund did not provide detailed information on the actual purpose and use of these grants. Around $98 \%$ of the 22.8 million euros distributed by the Strategic Press Development Fund were allocated to the traditional print press and not to new online projects or news media start-ups.

Another fund was introduced to promote the pluralism through allocating direct aids, in particular to help newspapers that attract not enough advertising revenues. For instance, the communist daily L'Humanité received 0.63 euros per selling copy, i.e. 1/3 of its selling price. Le Figaro and Le Monde are the most financially helped newspapers. They received in total around 16 million euros in 2013 (around $90 \%$ of this amount used to cover the increase of logistics and distribution costs) (Ministère de la Culture et de la Communication, 2015, 2016).

For many years, the money related to the numerous public aids programs for the news media sector cumulated up to around 1 billion euros for each year. In 2014, the overall amount of all public (direct and indirect) subsidies for the print press was 1.1 billion euros, which was around $15 \%$ of the total turnover of the sector in 2014. The total amount for direct aids was 137 million euros (mainly allocated to the print press) and 971 million euros for indirect aids (Spiil, 2015). Despite the well developed supporting system in France, the system did not really trigger innovations in the sector (Freiberg, 1981; Le Floch and Sonnac, 2005; Lardeau and Le Floch, 2014). Moreover, distribution, technological and business innovations that directly affected news media markets such as Internet, social media or technical devices were not created nor derived from news organizations or people working in these markets.

As of today, the French political and administrative system does not fully support the innovation processes in online news market. The system only allocates a small share of the State subsidies to this market. 


\section{$4 \quad$ Summary and Best Practices}

For many decades, the French State has developed numerous aids programs for news media including aid programs for innovative and modernization projects, in particular for newspapers. However, the evidence shows an enduring trend towards concentration in the different traditional news media markets in France. It is expected that this tendency will further increase in the short and middle term. The biggest and dominant press groups reinforce their positions in the regional daily newspaper market. As a result, the regional newspaper market has become more concentrated. Although the national daily newspaper market is still less concentrated-only Les Echos and Le Parisien-Aujourd'hui en France have the same owner - the concentration is also increasing in this market segment. In the last two decades, newcomers are all owned by new tycoons and billionaire entrepreneurs who actually share more or less the same economic as well as political ideas or concerns. They own worldwide conglomerates in which newspapers are fully secondary in terms of financial revenues.

Since the Liberation period (1944-1946) the structure of newspaper market has not changed dramatically. Daily newspapers have to be printed in printing plants controlled by a communist union ("syndicat CGT du Livre") that rules the workforce instead of the printing owner. The union de facto also controls Presstalis, the main French media distribution corporation. Due to this monopolistic position the printing and distribution system still works on principles defined in 1944 that reject free market competition. As a consequence, printing and distribution costs regularly increased and the owners of newspapers could not escape this situation. This lack of dynamism heavily burdens the capabilities for burgeoning an innovation spirit in the market of newspapers. In order to minimize the effects of an increase in costs, public authorities maintain the public subsidies system that is yet inefficient in triggering modernization and innovation. Most media leaders and journalism leaders agree with this status-quo that is more comfortable than change and innovation (Schwartzenberg, 2007). However political reasons-that are intertwined with the economy-represent the most highly decisive determinant of increasing concentration and lack of innovation spirit in news media markets. For instance, succeeding governments have never tried or achieved to break the uncompetitive rule in the printing and distribution system. In addition, public authorities and political leaders did never take action to break down neither the conditions for concentration reinforcement and the informal non-competition agreement between regional press groups nor act to preserve or reinforce fair competition in markets. Although they maintain the public subsidies system that contributes to endure this situation and foster the role of moguls, wealthy entrepreneurs and conglomerates who enter the national daily market for some years with no resistance.

We can draw the same conclusion for the national radio broadcasting market. It is not actually concentrated, although a few companies have a relatively dominant position. For instance, the group Radio France consists of many radio stations (including France Inter and France Info). Although the three other nationwide 
news stations (RTL, Europe 1, RMC) belong to different groups, these groups are run by billionaire tycoons who control other media sources as well.

The traditional news media markets (press, radio, and TV) are highly institutionalized in France. The French State plays a substantive role in the news media sector as regulator, supervisor and actor. Political organizations and individuals have historically strong relationships with their news media counterparts. A recent development is that powerful media tycoons are controlling more and more news media firms and outlets. Due to the strong institutionalization in news media markets in France the business and professional models are not adjusting enough to the changing requirement. As of today, they do not comply with current media consumption and changing markets conditions anymore. These highly institutionalized markets are thus not permeable to change through new incomers, new ideas or new practices; media companies are not familiar with R\&D approach, even in terms of editorial and content concerns. As a result these markets are strongly conservative and did never generate a culture of innovation.

Hence, the French news media markets are not innovation-centered nor have an orientation on innovation and change management. The few cases of innovation we mentioned are exceptions. Due to the fact of the lack of culture of innovation in the French news media markets no best practices in innovation can be drawn.

\section{$5 \quad$ Innovation Policy Recommendations}

Regarding the strong institutionalization of the French news media markets and the lack of culture of innovation, drawing recommendation for setting up the conditions for innovation policy is really challenging. It requires thinking out the box, challenging "the taken for granted", and creating material and business conditions so that companies are willing to take business and technological risks, to favor change. "The aim of innovation policies (...) is to foster the development of technologies that do not yet exist and whose business models and markets are unknowable. Organizations capable of inventing these technologies must be attracted or built, and the result of their labors must be channeled into economic growth. That means we're not talking about a process of long-term planning but one of continuous experimentation" (Innovation Policy Platform, 2016).

The following-workable and realistic_-suggestions can be given to plant the seeds of innovation spirit.

- Reform the curricula in journalism and media schools. This recommendation also includes the development of courses in Entrepreneurial Journalism and Innovation Journalism.

- The journalism and media schools should collaborate more with scientific, business or artistic schools; or should create co-curricula with these schools. This suggestion stimulates interaction between journalism students and other students, other ways of thinking, development of required capabilities, etc. 
- Reform the State subsidy system that is inefficient for many decades and does not focus on triggering innovation. This proposal requires that all actors involved in the news media markets should implement reforms which are already provided by numerous reports and studies. It also requires that French government should reduces the intensity or even break longtime relationships with particular individuals and organizations.

This final remark suggests that it is doubtful whether the recommended innovation policies could come from the insiders (Government, or mainstream media) who regulate, control and manage the highly institutionalized news media markets in France. It seems that they prefer to maintain the comfortable system rather than triggering and/or sustaining a risky reform that would force them to challenge the taken-for-granted practices and develop innovative strategy policies. It seems that innovation in the news media markets should come from outsiders and less dominant actors.

\section{References}

Albert, P., \& Sonnac, N. (2015). La presse française: au défi du numérique. Paris: La documentation française.

Benyahia-Kouider, O. (2011). Un si petit Monde. Paris: Fayard.

Charon, J.-M. (1991). La presse en France: de 1945 à nos jours. Paris: Seuil/Points.

Ministère de la Culture et de la Communication. (2015). Retrieved January 5, 2016, from http://www.culturecommunication.gouv.fr/Politiques-ministerielles/Presse/ Aides-a-la-presse/Le-fonds-strategique-pour-le-developpement-de-la-presse-aides-directes/4.Bilans-du-Fonds-strategique-pour-le-developpement-de-la-presse

Ministère de la Culture et de la Communication. (2016). Retrieved January 5, 2016, from http:// www.culturecommunication.gouv.fr/Politiques-ministerielles/Presse/Chiffres-statistiques

de la Motte, D. and Przyblyski, J. M. (1999). Making the news: Modernity \& the mass press in nineteenth-century France. Amherst, MA: The University of Massachusetts Press.

de Tarlé, A. (1980). The press and the state in France. In A. Smith (Ed.), Newspapers and democracy: International essays on a changing medium (pp. 127-148). Cambridge, MA: The MIT Press.

Eveno, P. (2003). L'argent de la presse française des années 1820 à nos jours. Paris: CTHS.

Freiberg, J. W. (1981). The French press: Class, state, and ideology. New York: Praeger.

Gabszewicz, J. and Sonnac, N. (2010). L'industrie des médias à l'ère numérique. Paris: La découverte.

Innovation Policy Platform. (2016). Innovation definitions and fundamentals. Retrieved May 2016, from https://www.innovationpolicyplatform.org/content/innovation-definitions-andfundamentals

Kuhn, R. (1995). The media in France. London: Routledge.

Lardeau, M. (2009, May 18-20). Innovation journalism: A French perspective. Paper presented at the 6th Conference on Innovation Journalism (InJo), Stanford.

Lardeau, M. (2013). Le surprenant succès de la revue XXI: quelques idées simples mais pertinentes en entreprenariat et innovation. In C. Ben-Hafaïedh \& S. Boubakeur (Eds.), De l'entrepreneuriat à la gouvernance: enjeux et perspectives (pp. 51-72). Paris: Lavoisier.

Lardeau, M. and Le Floch, P. (2014). France: Press subsidies-inefficient but enduring. In P. Murschetz (Ed.), State aid for newspapers-Theories, cases, actions (pp. 193-212). Berlin: Springer. 
Le Floch, P. and Sonnac, N. (2005). Economie de la presse. Paris: La découverte.

Médiamétrie. (2014, September). Usages des médias: quelles évolutions?

Médiamétrie. (2015a). Retrieved October 2016, from http://www.cbnews.fr/etudes/mediamatmensuel-tf1-et-m6-en-baisse-france-2-progresse-a1022873

Médiamétrie. (2015b). Retrieved October 2016, from http://www.mediametrie.fr/comportements/ communiques/usages-des-medias-quelles-evolutions.php?id $=1122$

Nordfors, D. (2004). The concept of innovation journalism and a programme for developing IT. Innovation Journalism, 1(1). http://www.nouveautes-tele.com/14862-audiences-radioavril-juin-2015-rtl-toujours-en-tete.html

Reporters Sans Frontières. (2015). 2015 World Press Freedom Index. Retrieved December 2015, from https://rsf.org/en/ranking/2015

Schwartzenberg, E. (2007). Spéciale dernière: qui veut la mort de la presse quotidienne française? Paris: Calmann-Lévy.

Spiil. (2015). Retrieved December 2015, from http://www.spiil.org/20150602/spiil-publie-unpanorama-complet-aides-presse,spiil.org 